\title{
The Accrual Effect on Future Earnings*
}

\section{KONAN CHAN}

Department of Finance, College of Management, National Taiwan University, 50, Lane 144, Section 4, Keelung Road Taipei, Taiwan 10660, Tel.: 886-2-23698955, Fax: 886-2-23660764

E-mail: kchan@mba.ntu.edu.tw

\section{NARASIMHAN JEGADEESH}

Goizueta Business School, Emory University, 1300 Clifton Road, Atlanta, GA 30322-2722, USA,

Tel.: (404) 727-4821

E-mail: Narasimhan.Jegadeesh@bus.emory.edu

\section{THEODORE SOUGIANNIS}

Department of Accountancy, College of Business, University of Illinois at Urbana-Champaign, 1206 South Sixth Street, Champaign, IL 61820, USA, Tel.: (217) 244-0555, Fax: (217) 244-0902; Athens Laboratory of Business Administration (ALBA), Athinas Ave \& 2A Areos Str., Vouliagmeni 16671, Athens, Greece

E-mail: sougiani@uiuc.edu

\begin{abstract}
Earnings manipulation has become a widespread practice for US corporations. However, most studies in the literature focus on whether certain incentives would facilitate managers to manipulate earnings and there has been little evidence documenting the consequences of earnings manipulation. This paper fills this gap by examining how current accruals affect future earnings (the accrual effect) and measuring the size of this effect. We find that the aggregate future earnings will decrease by $\$ 0.046$ and $\$ 0.096$, respectively, in the next one and three years for a $\$ 1$ increase of current accruals. Over the very long-term (25 years), $20 \%$ of current accruals will reverse. This negative accrual effect is more significant for firms with high price-earnings ratios, high market-tobook ratios and high accruals where earnings management is more likely to occur. We show that incorporating the accrual effect is useful in improving the accuracy of earnings forecasts for these firms. Accordingly, the empirical results are consistent with the notion that earnings management causes the negative relationship between current accruals and future earnings. In addition, this paper shows that one recently developed accrual model has better performance than the popularly cited model in identifying manipulated earnings.
\end{abstract}

Key words: earnings management, accrual reversal, cash flow Jones model, earnings prediction

JEL Classification: M41

A growing body of recent literature documents that future stock returns can be predicted by using accounting accruals. For example, Sloan (1996) finds that stocks with high accruals consistently underperform stocks with low accruals for three years. Teoh, Welch and Wong (1998a, 1998b) report that issuing firms (either IPOs or SEOs) with aggressive inflation of accruals experience worse performance than their counterparts by 20 to 30 percent over four post-issue years. Chan et al. (2003) further show that the success of an accrualbased strategy which buys firms with low accruals and sells firms with high accruals is not

*We appreciate helpful comments from Louis Chan, Josef Lakonishok, Chiawen Liu, two referees and seminar participants at 2002 PBFEA conference. 
attributable to the most important common factors of cross-section stock returns, such as size, book-to-market, and past returns.

One potential explanation for the return predictability of accruals is the "earnings management hypothesis". That is, firms with high accruals may be opportunistically using accruals to inflate reported earnings. However, investors tend to fixate on reported earnings and thus overlook the existence of earnings manipulation behavior, leading to an over-optimism on these firms. Since accruals are accounting adjustments to cash flows and should sum to zero over the life of a firm, the upwardly managed accruals are expected to be followed by reversals. Because reported earnings consist of cash flows and accruals, when current accruals reverse subsequently, future reported earnings will shrink as well. Accordingly, as earnings cannot keep up with the momentum, investors will adversely revise their expectations on firms' future performance, causing low future returns for stocks with high current accruals. Under this earnings management hypothesis, a fundamental issue relating the manipulation of current accruals to future price corrections is that current accruals have a negative impact on future earnings. However, the extant literature does not provide a direct assessment of the impact of current accruals on firms' future operating performance. The accrual effect on future earnings remains unclear and needs further research.

This paper tries to fill this gap by examining the accrual effect on future earnings. Although earnings management has received a lot of attention in the last decade, most prior studies focus on whether certain incentives would facilitate managers to manipulate earnings and there has been little evidence documenting the consequences of manipulating current earnings for future earnings. Since the manipulation of reported earnings has become a widespread practice, ${ }^{1}$ there is a strong need to recognize and measure the impact of such earnings management. By developing a model that quantifies the dollar effect of current accruals on future earnings, this paper examines not only the impact of current accruals on firm's future performance but also the pattern of accrual reversals. Because the same level of accruals in different types of firms may cause different degrees of impact on future earnings, this paper also investigates the accrual effects classified by firm characteristics. Under the earnings management hypothesis, the negative effects of accruals on future earnings are expected to be more significant for firms with a higher probability to manipulate earnings. In particular, firms with relatively high price levels, such as high price-earnings $(\mathrm{P} / \mathrm{E})$ or high market-to-book (M/B) stocks, are believed to have stronger incentives to manipulate earnings due to the greater impact on stock prices achieved by the same level of earnings manipulation. ${ }^{2}$ In addition, firms with high accruals should have a larger accrual impact on future earnings. This is because these firms may be using accruals to inflate current earnings. By allowing for different accrual effects among firms with distinct manipulation incentives, the accrual impact on future earnings can be measured with higher accuracy.

An important feature of this paper in quantifying the total impact of current accruals on future earnings lies in the anatomy of accrual reversals over a very long horizon ( 25 years). Anecdotal evidence suggests that earnings management is long-term in nature for some cases. For instance, Teoh, Welch and Wong (1998a) argue that IPO firms would aggressively manage both pre-issue and post-issue earnings to facilitate insider trading, maintain their reputation, and avoid lawsuits. Dechow, Sloan, and Sweeney (1996) examine firms investigated by the SEC for conducting earnings management, and report that $10 \%$ of their 
sample firms manipulate earnings for more than three years. If a firm manages earnings continuously for three years, the reversal of initially manipulated earnings will occur at earliest in the fourth year, and the subsequent accrual reversal could take place over a long horizon. Therefore, a comprehensive analysis of the total effect of accruals on future earnings must be performed over a long horizon to allow for the complete reversal of accruals.

To gauge the long-term effect of accruals on future earnings, we apply the vector autoregressive (VAR) procedure similar to that in Campbell and Ammer (1993). In the VAR model, we assume that earnings and accruals are two state variables which jointly determine their future values. The coefficients associating the current state variables with future earnings and accruals are estimated by running rolling-over time-series regressions for individual firms. The major advantage and motivation of using VAR in this study is that multi-period ahead forecasts can be obtained based on the short-term behavior of the state variables. As a result, this paper can include sample firms which have survived less than 25 years, and hence reduce the potential sample selection bias. In addition, allowing the coefficients to change across years and individual firms, the rolling-over time-series regressions explicitly account for the firm- and time-specific features of earnings management, and can generate more accurate estimates for the total accrual effects on future earnings.

In addition to assessing the importance of accruals on future earnings, this paper contributes to the existing literature in detecting earnings management. Specifically, it provides a richer array to evaluate accrual models in identifying unexpected accruals. Prior studies usually decompose accruals into non-discretionary accruals (NDA) and discretionary accruals (DA) where NDA is the expected accruals given firms' operations and conditions. Since DA is designed to measure manipulated earnings, if earnings management is present, DA should contribute to the negative accrual effects more than NDA does. Accordingly, examining the difference between DA and NDA effects on future earnings provides a new avenue to evaluate the performance of various accrual models. If an accrual model can identify stronger DA and weaker NDA effects than other models, then this model is a better model in detecting earnings management. ${ }^{3}$

An interesting application of measuring the accrual effects is in the prediction of future earnings. If investors predict earnings by naively extrapolating current earnings growth without recognizing the accrual effect, the predicted earnings may be consistently biased. If accrual effects are incorporated, the predicted earnings should be less biased and more accurate. This improvement of earnings predictions is expected to be more evident when the accrual effect is strong. Therefore, this paper examines whether and when to utilize the accrual effect in predicting future earnings.

Based on 58,815 time-series regressions from 2,914 sample firms, the results show that accruals are negatively related to future earnings. If firms increase accruals by $\$ 1$ today, the aggregate future earnings will decrease, on average, by $\$ 0.046$ and $\$ 0.096$, respectively, for the next one and three years. Over the very long-term (25 years), 20\% of accruals will reverse. This result indicates that about half of the long-term accrual effect occurs in the first three years. When grouped by different firm characteristics, the accrual effects are significantly different between high and low accrual firms. The accrual reversal for firms with high $\mathrm{P} / \mathrm{E}$ and $\mathrm{M} / \mathrm{B}$ ratios is also much stronger than their counterparts. Since firms with high accruals, $\mathrm{P} / \mathrm{E}$, and $\mathrm{M} / \mathrm{B}$ are more likely to take income-increasing actions, the strong 
accrual reversals associated with these firms suggest the existence of earnings management and demonstrate its significant impact on future earnings.

To examine the separate effects of DA and NDA on future earnings, we employ the Jones (1991) and the cash flow Jones (CF-Jones) models, to estimate DA and NDA. The Jones model is chosen here because of its popularity in the literature. However, recent papers argue that the Jones model suffers the omitted variable problem and thus generates imprecise parameter estimates. To mitigate these problems, we apply the CF-Jones model, which incorporates changes in cash flows into the Jones model, to identify DA. This CF-Jones model is motivated by Dechow (1994) who finds a strong negative relationship between accruals and changes in cash flows for individual firms. Our empirical results show that the CF-Jones model performs better in fitting the accrual data than the Jones model. The mean adjusted- $\mathrm{R}^{2}$ is $57.30 \%$ for the CF-Jones model, but only $24.37 \%$ for the Jones model. Regarding the impact on future earnings, the effect of DA from the Jones model, on average, is smaller than that of NDA. On the contrary, DA from the CF-Jones model exhibits a more significant adverse impact on future earnings than its NDA counterpart, especially for firms with high accruals, $\mathrm{P} / \mathrm{E}$ and $\mathrm{M} / \mathrm{B}$. This result along with the higher power to explain accrual variability suggests that the CF-Jones model is a better model in detecting earnings management. Since the CF-Jones model is fairly recent in the literature ${ }^{4}$ and hasn't received much attention on its performance, our result provides a new tool for future research in identifying manipulated earnings.

We also make earnings predictions based on current earnings and accruals, as well as the coefficients from the VAR model. On average, adding accruals reduces negative biases that are present when earnings prediction is based only on current earnings. However, since accruals are much more volatile than earnings, the accuracy of predicted earnings obtained by including the accrual information is decreased. Nevertheless, for firms with high accruals volatility, the VAR model can generate earnings forecasts with better accuracy. The VAR model is also useful in improving earnings predictions for firms with high accruals, high $\mathrm{P} / \mathrm{E}$, and high $\mathrm{M} / \mathrm{B}$ where earnings management is likely to occur.

The rest of this paper is organized as follows. Section 1 describes the sample and methodology used in this study. Section 2 presents estimation results of the accrual impact on future earnings. Section 3 examines the long-term effects of DA and NDA separately, and compares the performance of two accrual models used to compute DA and NDA. The results of earnings predictions are discussed in Section 4. Section 5 concludes the paper.

\section{Sample and methodology}

\subsection{The sample}

The sample is selected from all NYSE/AMEX/NASDAQ companies covered in both the Center for Research in Security Prices (CRSP) and merged Compustat files from 1950 to 1996. Only domestic, primary, and non-financial stocks are considered in this study. Each sample firm is required to have at least 11 consecutive annual accruals and earnings data in order to estimate the accrual effect from time-series regressions. ${ }^{5}$ Earnings are measured by net income before extraordinary items (Compustat item 18). Accruals are defined as in 
Eq. (1) to be consistent with the earnings management literature (Jones (1991), and Dechow, Sloan and Sweeney (1995)). ${ }^{6}$

$$
\text { Accruals }=(\Delta \mathrm{CA}-\Delta \mathrm{Cash})-(\Delta \mathrm{CL}-\Delta \mathrm{STD})-\mathrm{DEP}
$$

where $\Delta \mathrm{CA}=$ change in current assets (Compustat item 4)

$\Delta$ Cash $=$ change in cash (Compustat item 1)

$\Delta \mathrm{CL}=$ change in current liabilities (Compustat item 5)

$\triangle \mathrm{STD}=$ change in debt included in current liabilities (Compustat item 34)

$\mathrm{DEP}=$ depreciation and amortization (Compustat item 14)

We also eliminate firms which do not have available stock prices to ensure that sample firms are publicly traded and observable. The final sample includes 58,815 firm-year observations from 2,914 firms during the period of 1963 to 1996.

\subsection{The VAR Approach}

To model the relationship between earnings and accruals, we consider a simple accounting setting where earnings $(E)$ and accruals $(A)$ are two state variables. Suppose they follow a first-order VAR system as shown in Eqs. (2) and (3). The error terms, $u_{t}$ and $v_{t}$, are i.i.d. $N(0,1)$.

$$
\begin{aligned}
& E_{t+1}=a_{0}+a_{1} E_{t}+a_{2} A_{t}+u_{t} \\
& A_{t+1}=b_{0}+b_{1} E_{t}+b_{2} A_{t}+v_{t}
\end{aligned}
$$

In this VAR system, future state variables are determined by their current values jointly. ${ }^{7}$

To examine how current accruals affect future earnings, $a_{2}$ is the coefficient of interest. It measures the extent to which earnings in the next period will be affected by a $\$ 1$ change of current accruals while holding current earnings constant. If managers manipulate reported earnings by inflating (decreasing) accruals, the future accruals will reverse and thus reduce (increase) future earnings, causing $a_{2}$ to be negative. As a result, if $a_{2}$ is negative empirically, it will be consistent with the earnings management hypothesis.

An alternative approach of modeling the VAR system is to replace earnings with cash flows as the state variable since earnings equal to cash flows $(C)$ plus accruals. Equation (2), therefore, can be written as

$$
E_{t+1}=h_{0}+h_{1} C_{t}+h_{2} A_{t}+z_{t}
$$

where $h_{1}=a_{1}$ and $h_{2}=a_{1}+a_{2}$ (or $a_{2}=h_{2}-h_{1}$ ). From Eq. (4), the impact of current accruals on future earnings will be $h_{2}$ rather than $a_{2}$.

Equation (4) is not considered in this paper, however, due to its two drawbacks to estimate the amount of accrual reversal. First, the purpose of detecting the accrual reversal is to investigate how accruals in the current period affect future earnings. If earnings is the variable of interest, controlling for current earnings is more important than controlling for current cash flows. Dechow (1994) finds that earnings are more value-relevant than cash 
flows. In other words, the contemporaneous association between stock returns and earnings is stronger than that between stock returns and cash flows. Dechow, Kothari and Watts (1998), among others, further document that current earnings better forecast future cash flows than current cash flows. These results suggest that earnings contain more information than cash flows, and are more economically meaningful. Therefore, controlling for current earnings provides a better way to account for firms' business condition and general economic trends, and is more appropriate in measuring the accrual effects on future earnings. Second, by using a cross-sectional regression as Eq. (4), Sloan (1996) shows that accruals exhibit lower persistence than cash flows in predicting future earnings, i.e., $h_{2}<h_{1}$. The reason for the lower persistence of accruals is that total accruals, which include deferrals, allocations and depreciation, are estimated based on accounting rules and are subject to managers' distortion. Financial statement analysis textbooks, such as Bernstein (1993), Schilit (1993), and Kieso and Weygandt (1998), all provide the same notion about accruals. This implies that the difference in the persistence of current accruals and cash flows to predict future earnings, or $h_{2}-h_{1}$, is due to earnings management. Since $a_{2}=h_{2}-h_{1}$, the coefficient of interest in this paper should be $a_{2}$, rather than $h_{2}$.

One major concern for the VAR system is the validity of specifications in Eqs. (2) and (3). In particular, if either one of the two time-series of earnings and accruals is not stationary while the other one is, the VAR system applied in this paper will have poor time-series properties and thus may not generate accurate estimates of accrual effects. To investigate this issue, we perform the unit root tests on both earnings and accruals for individual firms. We find that only about $2 \%(0.2 \%)$ of the sample firms contain a unit root in their earnings (accruals) data. ${ }^{8}$ This result suggests that both earnings and accruals are stationary processes for most of the sample observations. As a result, the specifications in Eqs. (2) and (3) do not impose any econometric problems.

The advantage and motivation of using VAR in this paper is that multi-period ahead forecasts can be easily derived based on the short-term behavior of state variables. As a result, this paper can include sample firms which have survived less than 25 years, and hence reduce the potential sample selection bias. To measure the total accrual impact on future earnings, Eqs. (2) and (3) are repeatedly substituted into the system over different horizons. The future earnings, accordingly, are expressed in terms of current earnings and accruals as follows:

$$
E_{t+k}=\gamma_{0 k}+\gamma_{1 k} E_{t}+\gamma_{2 k} A_{t}+w_{t k}
$$

where $\gamma_{1 k}$ and $\gamma_{2 k}$ are $(1,1)$ th and $(1,2)$ th element of $\mathbf{Q}^{k}$, respectively, and

$$
\mathbf{Q}=\left[\begin{array}{ll}
a_{1} & a_{2} \\
b_{1} & b_{2}
\end{array}\right]
$$

Summing Eq. (5) over different values of $k$, the aggregate future earnings can be written as

$$
\sum_{j=1}^{k} E_{t+j}=\sum_{j=1}^{k} \gamma_{0 j}+\left(\sum_{j=1}^{k} \gamma_{1 j}\right) E_{t}+\left(\sum_{j=1}^{k} \gamma_{2 j}\right) A_{t}+\sum_{j=1}^{k} w_{t j}
$$


Therefore, the total impact of current accruals on future earnings cumulative over $k$ years is $\sum_{j=1}^{k} \gamma_{2 j}$, which is the $(1,2)$ th element of $\sum_{j=1}^{k} \mathbf{Q}^{j}$.

To estimate the transition matrix, $\mathbf{Q}$, we run rolling-over time-series regressions (Eqs. (2) and (3)) for each sample firm in each year based on all available past earnings and accruals, as long as the sample firm has at least 11 consecutive annual data. To control for heteroskedasticity, earnings and accruals, as well as the intercept, are scaled by total assets at time $t$. Once $\mathbf{Q}$ is estimated, the total accrual effects on future earnings over different horizons can be obtained by continuously compounding $\mathbf{Q}$ based on Eq. (6). ${ }^{9}$

In this paper, the maximum $k$ is 25 in order to allow for the complete reversal of accruals. Anecdotal evidence suggests that earnings management is long-term in nature for some cases. For example, Teoh, Welch and Wong (1998a) argue that IPO firms would aggressively manage both pre-issue and post-issue earnings. Dechow, Sloan, and Sweeney (1996) examine firms investigated by SEC for conducting earnings management and find that $10 \%$ of their sample firms manipulate earnings for more than three years, including a few firms performing earnings management over six years. If a firm manages earnings continuously for three years, the reversal of initially manipulated earnings will occur at earliest in the fourth year, and the subsequent accrual reversal could take a long time. Therefore, a comprehensive analysis of the total effect of current accruals on future earnings must be performed over long horizons so that accruals can reverse completely.

\subsection{Estimation of DA and NDA effects}

Most of the existing earnings management studies focus on the analysis of discretionary accruals (DA), which proxy for management discretion on reported earnings. On the other hand, non-discretionary accruals (NDA), the difference between total accruals and DA, are not related to earnings management because they simply reflect business conditions. Since accruals equal to DA plus NDA, this paper also examines the separate effects of current DA and NDA on future earnings. The purpose of doing so is to test whether the negative accrual effects are due to earnings management. If earnings management is present, DA should contribute to the negative accrual effects more than NDA does. On the other hand, comparing the difference between DA and NDA effects provides a way to evaluate the performance of accrual models. If an accrual model can identify stronger DA and weaker NDA effects than other models then this model is a better model to separate the accrual components and detect earnings management.

To estimate DA and NDA, we use the most popular accrual model in the literature, the Jones (1991) model. This model separates accruals into DA and NDA by regressing total accruals on the change in sales $(\triangle$ Sales $)$ and property, plant and equipment $(P P E)$, all scaled by total assets, as shown in Eq. (7).

$$
\frac{\text { Accrual }_{i}}{\mathrm{TA}_{i}}=\alpha_{0} \frac{1}{\mathrm{TA}_{i}}+\alpha_{1} \frac{\Delta \text { Sales }_{i}}{\mathrm{TA}_{i}}+\alpha_{2} \frac{\mathrm{PPE}_{i}}{\mathrm{TA}_{i}}+\varepsilon_{i}
$$

NDA is the fitted value of Eq. (7) and DA is the regression residual. In the Jones model, the change in sales is used to control for firm growth since working capital is closely related 
to sales, while PPE is used to control for depreciation expenses contained in accruals. In other words, NDA is the expected accruals given firm's growth and fixed assets, while DA represents the unexpected accruals.

Same as in Teoh, Welch and Wong (1998a, 1998b), we decompose accruals into DA and NDA by using cross-sectional regressions for each industry in each year, rather than timeseries regressions for each individual firm. The reason for applying the cross-sectional Jones model is because it has the advantage of controlling for industry-wide effects on accruals (Defond and Jiambalvo (1994) and Kasznik (1999)). In addition, cross-sectional regressions do not impose requirements for long series of data. This feature can greatly increase the sample size and result in more precise estimated coefficients. In fact, Subramanyam (1996) finds that the accuracy of the estimated coefficients in Eq. (7) is higher in the cross-sectional than in the time-series version due to the larger number of observations in the cross-sectional regressions.

In spite of its popularity in the earnings management literature, the Jones model has received considerable criticism. For example, Dechow, Sloan and Sweeney (1995) and Guay, Kothari and Watts (1996) find that DA from the Jones model is imprecise due to the large variation of the estimated coefficients, even though the Jones model exhibits more power than other existing accrual models in detecting earnings management. Healy (1996) and Bernard and Skinner (1996) also argue that, because of the omitted variable problem, the Jones model does a poor job in accurately separating DA and NDA.

To mitigate the measurement error problem of the Jones model, we apply a newly developed accrual model, the cash flows Jones (CF-Jones) model, to estimate DA and NDA. This CF-Jones model is motivated by the evidence that changes in cash flows are closely and negatively related to accruals (Dechow, 1994). The negative relationship occurs because generally accepted accounting principles allow managers to use accruals to alter the timing of cash flows so that earnings can closely reflect the underlying performance of firms. To account for this strong negative relationship, the CF-Jones model includes the change in cash flows $(\triangle C F)$ as a third independent variable as shown in Eq. (8).

$$
\frac{\text { Accrual }_{i}}{\mathrm{TA}_{i}}=\beta_{0} \frac{1}{\mathrm{TA}_{i}}+\beta_{1} \frac{\Delta \text { Sales }_{i}}{\mathrm{TA}_{i}}+\beta_{2} \frac{\mathrm{PPE}_{i}}{\mathrm{TA}_{i}}+\beta_{3} \frac{\Delta \mathrm{CF}_{i}}{\mathrm{TA}_{i}}+\varepsilon_{i}
$$

Since total accruals equal DA plus NDA, the VAR system of equations (2) and (3) can be expressed as Eqs. (9), (10) and (11).

$$
\begin{aligned}
E_{t+1} & =c_{0}+c_{1} E_{t}+c_{2} \mathrm{DA}_{t}+c_{3} \mathrm{NDA}_{t}+\phi_{1 t} \\
\mathrm{DA}_{t+1} & =d_{0}+d_{1} E_{t}+d_{2} \mathrm{DA}_{t}+d_{3} \mathrm{NDA}_{t}+\phi_{2 t} \\
\mathrm{NDA}_{t+1} & =e_{0}+e_{1} E_{t}+e_{2} \mathrm{DA}_{t}+e_{3} \mathrm{NDA}_{t}+\phi_{3 t}
\end{aligned}
$$

Similarly, Eqs. (5) and (6) can be re-written as Eqs. (12) and (13), respectively.

$$
E_{t+k}=\delta_{0 k}+\delta_{1 k} E_{t}+\delta_{2 k} \mathrm{DA}_{t}+\delta_{3 k} \mathrm{NDA}_{t}+\eta_{t k}
$$


where $\delta_{1 k}, \delta_{2 k}$ and $\delta_{3 k}$ are $(1,1)$ th, $(1,2)$ th and $(1,3)$ th element of $\mathbf{R}^{k}$, respectively, and

$$
\begin{aligned}
\mathbf{R} & =\left[\begin{array}{lll}
c_{1} & c_{2} & c_{3} \\
d_{1} & d_{2} & d_{3} \\
e_{1} & e_{2} & e_{3}
\end{array}\right] \\
\sum_{j=1}^{k} E_{t+j} & =\sum_{j=1}^{k} \delta_{0 j}+\left(\sum_{j=1}^{k} \delta_{1 j}\right) E_{t}+\left(\sum_{j=1}^{k} \delta_{2 j}\right) \mathrm{DA}_{t}+\left(\sum_{j=1}^{k} \delta_{3 j}\right) \mathrm{NDA}_{t}+\sum_{j=1}^{k} \eta_{t j}
\end{aligned}
$$

Based on Eq. (13), the total effects of DA and NDA on future earnings cumulative over $k$ years are $\sum_{j=1}^{k} \delta_{2 j}$ and $\sum_{j=1}^{k} \delta_{3 j}$, respectively.

\subsection{Earnings predictions}

One major application of studying accrual effects is to improve earnings predictions. To test whether incorporating the accrual effects quantified by this paper is useful, the earnings predictions are performed using the estimated coefficients from the VAR model. Suppose $\hat{a}_{i}(i=0,1,2)$ are the estimated coefficients from Eq. (2) using all available time-series data up to time $t$. Then the next period earnings forecast can be obtained by the following equation:

$$
\hat{E}_{t+1}=\hat{a}_{0}+\hat{a}_{1} E_{t}+\hat{a}_{2} A_{t}
$$

The predicted accruals at time $t+1\left(\hat{A}_{t+1}\right)$ can be derived in the same fashion. Repeatedly substituting the predicted earnings and accruals into Eq. (14) results in the two- and threeyear ahead earnings forecasts as follows:

$$
\hat{E}_{t+k+1}=\hat{a}_{0}+\hat{a}_{1} \hat{E}_{t+k}+\hat{a}_{2} \hat{A}_{t+k} \quad(k=1,2)
$$

The benchmark employed to evaluate the earnings predictions of the VAR model is a simple model which reflects the "naive earnings fixation" behavior of investors as in Eq. (16).

$$
E_{t+1}=q_{0}+q_{1} E_{t}+v_{t}
$$

This Naïve model assumes that investors forecast future earnings by extrapolating the earnings growth without considering the accrual impact on future earnings. Similar to the earnings predictions of the VAR model, the predicted earnings from the Naïve model in the next period is

$$
\hat{E}_{t+1}=\hat{q}_{0}+\hat{q}_{1} E_{t}
$$


where $\hat{q}_{0}$ and $\hat{q}_{1}$ are the estimated coefficients of Eq. (16) using all available time-series data up to time $t$, and two- and three-year ahead earnings forecasts are

$$
\hat{E}_{t+k+1}=\hat{q}_{0}+\hat{q}_{1} \hat{E}_{t+k} \quad(k=1,2)
$$

The earnings prediction errors $\left(\mathrm{EPE}_{t n}\right) n$ years from time $t$ are used to evaluate the performance of the VAR and the Naïve models in predicting earnings and defined as follows:

$$
\mathrm{EPE}_{t n}=\left(\hat{E}_{t+n}-E_{t+n}\right) / \mathrm{TA}_{t+n-1} \quad(n=1,2,3)
$$

where $\hat{E}_{t+n}$ is the predicted earnings from either the VAR or the Naive model, $E_{t+n}$ is the actual earnings at time $t+n$, and $\mathrm{TA}_{t+n-1}$ is the lagged total assets. The accuracy of earnings forecasts is measured by the absolute earnings prediction errors (AEPE) which are the absolute values of EPE.

\section{Estimation of the accrual effects on future earnings}

The first row of Table 1 reports average cumulative effects of accruals on future earnings obtained from the estimation of Eq. (6).$^{10}$ It is evident that accruals exhibit a negative impact on future earnings. If firms manage accruals upwards by $\$ 1$ today, on average, earnings will decrease by $\$ 0.046$ in the following year, and three- and five-year aggregate future earnings will fall by $\$ 0.096$ and $\$ 0.128$, respectively. Over the very long-term ( 25 years), $\$ 0.202$ of aggregate earnings will be impaired due to the reversal of a $\$ 1$ increase in current accruals.

Table 1. Cumulative accrual effects on future earnings: by years

\begin{tabular}{ccrrrrrrrrrr}
\hline Period & \multirow{2}{*}{ No. of firms } & Yr 1 & Yr2 & Yr 3 & Yr 4 & Yr 5 & Yr 10 & Yr 15 & Yr 20 & Yr 25 \\
\hline $63-96$ & \multirow{2}{*}{815} & -0.046 & -0.072 & -0.096 & -0.113 & -0.128 & -0.168 & -0.186 & -0.197 & -0.202 \\
& & $(0.23)$ & $(0.35)$ & $(0.47)$ & $(0.56)$ & $(0.63)$ & $(0.83)$ & $(0.92)$ & $(0.98)$ & $(1.00)$ \\
Subperiod & & & & & & & & & & \\
$63-69$ & \multirow{2}{*}{261} & -0.036 & -0.055 & -0.071 & -0.081 & -0.093 & -0.125 & -0.138 & -0.141 & -0.144 \\
& & $(0.25)$ & $(0.38)$ & $(0.49)$ & $(0.56)$ & $(0.64)$ & $(0.86)$ & $(0.96)$ & $(0.98)$ & $(1.00)$ \\
$70-79$ & \multirow{2}{*}{595} & -0.044 & -0.066 & -0.088 & -0.104 & -0.119 & -0.161 & -0.186 & -0.201 & -0.206 \\
& & $(0.21)$ & $(0.32)$ & $(0.43)$ & $(0.51)$ & $(0.58)$ & $(0.78)$ & $(0.90)$ & $(0.98)$ & $(1.00)$ \\
$80-89$ & \multirow{2}{*}{1122} & -0.053 & -0.084 & -0.114 & -0.136 & -0.153 & -0.196 & -0.217 & -0.232 & -0.240 \\
& & $(0.22)$ & $(0.35)$ & $(0.47)$ & $(0.57)$ & $(0.64)$ & $(0.82)$ & $(0.91)$ & $(0.97)$ & $(1.00)$ \\
$90-96$ & \multirow{2}{*}{1242} & -0.050 & -0.079 & -0.105 & -0.123 & -0.139 & -0.180 & -0.192 & -0.196 & -0.200 \\
& & $(0.25)$ & $(0.40)$ & $(0.53)$ & $(0.62)$ & $(0.70)$ & $(0.90)$ & $(0.96)$ & $(0.98)$ & $(1.00)$ \\
\hline
\end{tabular}

Sample firms include all domestic, primary, and non-financial stocks covered in both Compustat and CRSP and with at least 12 year accruals and earnings. Accruals are defined as the change in non-cash working capital minus depreciation, and earnings are net income before extraordinary items. In each year from 1963 to 1996, time-series regressions of Eqs. (2) and (3) are estimated and the accrual effects on future earnings cumulative over $k(k=1$, $2,3,4,5,10,15,20,25)$ years as shown in Eq. (6) are calculated for individual firms. The median value of the accrual effects is first obtained in each year. The numbers in the table represent the averages of these annual median accrual effects. "No. of firms" is the average number of firms across the period indicated. Numbers in the parenthesis show the ratio of the accrual effect cumulative over $k$ years to the accrual effect cumulative over 25 years. 
While not reported in Table 1, the average accrual effect cumulative over each horizon is statistically significant at the $0.1 \%$ level, using either $t$-tests or Wilcoxon signed-rank tests. ${ }^{11}$ The negative accrual effects in Table 1 suggest the existence of earnings management because without the presence of earnings management accruals should not consistently affect future earnings once current earnings are controlled for. Since at least $20 \%$ of current accruals will reverse eventually, the result also points out the significant impact of accruals on future earnings.

To examine the pattern of accrual reversals, we divide the cumulative accrual effect for each horizon by the 25-year accrual effect, assuming that accruals completely reverse in 25 years. The results are shown in the parentheses. As expected, the largest accrual reversal occurs in the first year with $23 \%$ of the total reversal. Nearly half $(47 \%)$ of the long-term accrual effect is realized in the first three years. This finding is consistent with results in Sloan (1996) and Chan et al. (2003) that stocks with high accruals consistently underperform stocks with low accruals for three post-formation years. Since the annual incremental accrual effect is less than 0.01 after year 5 and only 0.001 after year 20, the accrual reversal seems to converge in the long-term. This pattern of accrual reversals is very similar across different periods.

Table 2 reports the accrual effects categorized by firm characteristics. The purpose of this analysis is to test whether the negative accrual effect is due to earnings management. If earnings management leads to the negative relationship between accruals and future earnings, this negative relationship should be stronger for firms which are more likely to manipulate earnings. For example, high accrual firms may be opportunistically using accruals to inflate earnings and are expected to experience significant accrual reversals. High P/E firms have stronger incentives to manage earnings upwards than low P/E firms since their price impact is remarkably larger given the same amount of manipulated earnings. Similarly, the relatively high price level for high M/B firms may induce managers to manage earnings to achieve the desired price appreciation.

The results in Table 2 are consistent with the above hypothesis. The highest $\mathrm{P} / \mathrm{E}$ firms have strong negative accrual effects on future earnings-39\% of current accruals will reverse in the long-run. With the only exception of the middle portfolio the higher the P/E ratio the larger the accrual reversal. The accrual effects are significantly different between the highest and lowest $\mathrm{P} / \mathrm{E}$ firms. Similarly, the highest $\mathrm{M} / \mathrm{B}$ firms consistently experience more accrual reversals over different horizons while the accrual effect is small for the lowest $\mathrm{M} / \mathrm{B}$ firms. When grouped by accruals, the highest accrual firms do show stronger accrual effects than the lowest accrual firms, and the difference is highly significant. Since high $\mathrm{P} / \mathrm{E}$, high $\mathrm{M} / \mathrm{B}$, and high accrual firms are more subject to earnings management, the significant accrual effects associated with these firms suggest that earnings management can be the cause of negative accrual effects on future earnings.

An alternative possible explanation for the negative accrual effects is that a few poorly performing industries experience substantial accrual reversals and thus dominate the results of the whole sample. While not reported here, the analysis of accrual effects classified by industries shows that accruals negatively affect future earnings across all industries. The median values for all industries are very close to the average levels in Table 1, suggesting that results in Tables 1 and 2 are not due to the industry effect. 
Table 2. Cumulative accrual effects on future earnings: by characteristics

\begin{tabular}{|c|c|c|c|c|c|c|c|c|c|c|c|}
\hline $\begin{array}{l}\text { Sorting } \\
\text { variable }\end{array}$ & $\begin{array}{l}\text { No. of } \\
\text { yrs }\end{array}$ & $\begin{array}{l}\text { No. of } \\
\text { firms }\end{array}$ & Yr 1 & Yr 2 & Yr 3 & Yr 4 & Yr 5 & Yr 10 & Yr 15 & Yr 20 & Yr 25 \\
\hline \multicolumn{12}{|l|}{$\mathrm{P} / \mathrm{E}$} \\
\hline Low & 34 & 159 & -0.039 & -0.056 & -0.072 & -0.084 & -0.094 & -0.116 & -0.127 & -0.130 & -0.132 \\
\hline 2 & 34 & 147 & -0.038 & -0.059 & -0.078 & -0.094 & -0.104 & -0.135 & -0.149 & -0.158 & -0.165 \\
\hline 3 & 34 & 137 & -0.071 & -0.119 & -0.162 & -0.189 & -0.213 & -0.296 & -0.338 & -0.364 & -0.379 \\
\hline 4 & 34 & 152 & -0.038 & -0.060 & -0.081 & -0.096 & -0.107 & -0.140 & -0.153 & -0.161 & -0.165 \\
\hline \multirow[t]{3}{*}{ High } & 34 & 181 & -0.051 & -0.085 & -0.118 & -0.144 & -0.169 & -0.261 & -0.326 & -0.359 & -0.391 \\
\hline & \multicolumn{2}{|c|}{ High-Low } & -0.012 & -0.029 & -0.046 & -0.060 & -0.075 & -0.145 & -0.200 & -0.228 & -0.259 \\
\hline & & $t$-stat & -3.89 & -5.52 & -6.96 & -6.6 & -6.85 & -7.99 & -7.58 & -7.55 & -7.18 \\
\hline \multicolumn{12}{|l|}{$\mathrm{M} / \mathrm{B}$} \\
\hline Low & 24 & 126 & -0.035 & -0.051 & -0.063 & -0.070 & -0.076 & -0.083 & -0.083 & -0.085 & -0.085 \\
\hline 2 & 24 & 112 & -0.049 & -0.070 & -0.085 & -0.098 & -0.111 & -0.138 & -0.146 & -0.151 & -0.152 \\
\hline 3 & 24 & 112 & -0.038 & -0.064 & -0.083 & -0.096 & -0.108 & -0.142 & -0.150 & -0.160 & -0.169 \\
\hline 4 & 24 & 138 & -0.038 & -0.057 & -0.078 & -0.088 & -0.095 & -0.117 & -0.125 & -0.127 & -0.128 \\
\hline \multirow[t]{3}{*}{ High } & 24 & 231 & -0.052 & -0.081 & -0.110 & -0.127 & -0.145 & -0.187 & -0.204 & -0.213 & -0.215 \\
\hline & \multicolumn{2}{|c|}{ High-Low } & -0.017 & -0.030 & -0.047 & -0.057 & -0.069 & -0.104 & -0.121 & -0.128 & -0.130 \\
\hline & & $t$-stat & -2.42 & -2.67 & -3.25 & -3.39 & -3.58 & -4.15 & -4.54 & -4.65 & -4.69 \\
\hline \multicolumn{12}{|c|}{ Accruals/TA } \\
\hline Low & 34 & 140 & -0.022 & -0.036 & -0.046 & -0.053 & -0.061 & -0.080 & -0.088 & -0.095 & -0.098 \\
\hline 2 & 34 & 131 & -0.051 & -0.083 & -0.115 & -0.142 & -0.166 & -0.248 & -0.313 & -0.363 & -0.386 \\
\hline 3 & 34 & 132 & -0.045 & -0.075 & -0.103 & -0.123 & -0.136 & -0.184 & -0.207 & -0.218 & -0.226 \\
\hline 4 & 34 & 181 & -0.059 & -0.095 & -0.129 & -0.147 & -0.164 & -0.204 & -0.223 & -0.236 & -0.247 \\
\hline \multirow[t]{3}{*}{ High } & 34 & 230 & -0.047 & -0.071 & -0.094 & -0.108 & -0.121 & -0.160 & -0.174 & -0.182 & -0.184 \\
\hline & \multicolumn{2}{|c|}{ High-Low } & -0.025 & -0.035 & -0.048 & -0.055 & -0.060 & -0.080 & -0.086 & -0.087 & -0.086 \\
\hline & & $t$-stat & -11.22 & -9.57 & -10.25 & -9.98 & -9.57 & -8.54 & -8.16 & -7.48 & -6.92 \\
\hline
\end{tabular}

In each year from 1963 to 1996, time-series regressions of Eqs. (2) and (3) are estimated and accrual effects on future earnings cumulative over $k(k=1,2,3,4,5,10,15,20,25)$ years as shown in Eq. (6) are calculated for individual firms. The median values of the accrual effects for different characteristics quintiles are first obtained in each year. The numbers in the table represent the averages of these annual median accrual effects. TA is total assets matched with the time when accruals are measured. Accruals/TA, P/E, and M/B are based on the first year data available for each sample firm. The rankings of Accruals/TA (P/E) are based on all sample firms with accruals (positive earnings) available in each year from 1953 to 1986. The rankings of M/B are based on NYSE firms with positive book values from 1963 to 1986 . "No. of firms" is the average number of firms across the sample period. $t$-stat reports the $t$-values testing the difference of the accrual effects between the highest and lowest quintiles.

\section{DA and NDA effects on future earnings}

Table 3 shows summary statistics of parameter estimates of the Jones and CF-Jones models. Apparently, the CF-Jones model performs much better than the Jones model in fitting the accrual data. The mean adjusted- $\mathrm{R}^{2}$ is $57.30 \%$ for the CF-Jones model, which is more than twice of the mean adjusted- $\mathrm{R}^{2}(24.37 \%)$ for the Jones model. This result indicates that adding changes in cash flows can significantly improve the explanatory power of the Jones model. Parameter estimates are also more accurate under the CF-Jones model. For example, the standard deviation is 0.051 for $\beta_{1}$ and 0.015 for $\beta_{2}$ which is less than that of $\alpha_{1}(0.066)$ and $\alpha_{2}(0.018)$, respectively. In addition, a higher percentage of regressions 
Table 3. Estimated coefficients for the Jones and CF-Jones models

\begin{tabular}{|c|c|c|c|c|c|c|c|c|c|c|c|}
\hline & $\alpha_{0}$ & \multicolumn{2}{|l|}{$\alpha_{1}$} & $\alpha_{2}$ & $t\left(\alpha_{0}\right)$ & $t\left(\alpha_{1}\right)$ & $t\left(\alpha_{2}\right)$ & \multicolumn{2}{|c|}{ adj. $R^{2}$} & \multicolumn{2}{|c|}{ No. of firms } \\
\hline \multicolumn{12}{|c|}{ Panel A: Jones model } \\
\hline Mean & 0.063 & \multicolumn{2}{|c|}{0.107} & -0.057 & 0.63 & 5.94 & -10.33 & \multicolumn{2}{|c|}{$24.37 \%$} & 60 & \\
\hline Min & -0.155 & \multicolumn{2}{|c|}{-0.020} & -0.124 & -1.74 & -0.71 & -24.64 & \multicolumn{2}{|c|}{$11.97 \%$} & 13 & \\
\hline 25 percentile & -0.012 & \multicolumn{2}{|c|}{0.063} & -0.068 & -0.08 & 2.17 & -13.42 & \multicolumn{2}{|c|}{$19.64 \%$} & 28 & \\
\hline Median & 0.034 & \multicolumn{2}{|c|}{0.110} & -0.053 & 0.52 & 5.94 & -8.84 & \multicolumn{2}{|c|}{$22.76 \%$} & 53 & \\
\hline 75 percentile & 0.118 & 0.15 & & -0.044 & 1.21 & 8.34 & -5.72 & 30.1 & $8 \%$ & 70 & \\
\hline Max & 0.525 & 0.2 & & -0.033 & 2.88 & 13.99 & -2.14 & 45.9 & $5 \%$ & 186 & \\
\hline Std. dev. & 0.121 & 0.0 & & 0.018 & 1.17 & 4.11 & 5.68 & $8.0^{-}$ & $7 \%$ & 41 & \\
\hline No. of negative & 682 & 247 & & 1301 & & & & & & & \\
\hline$\%$ of negative & 0.480 & $0.1^{7}$ & & 0.916 & & & & & & & \\
\hline & $\beta_{0}$ & $\beta_{1}$ & $\beta_{2}$ & $\beta_{3}$ & $t\left(\beta_{0}\right)$ & $t\left(\beta_{1}\right)$ & $t\left(\beta_{2}\right)$ & $t\left(\beta_{3}\right)$ & adj. & & $\begin{array}{l}\text { No. of } \\
\text { firms }\end{array}$ \\
\hline Panel B: CF-Jones & model & & & & & & & & & & \\
\hline Mean & 0.023 & 0.109 & -0.052 & $2-0.454$ & 0.30 & 9.34 & -12.52 & -14.24 & 57.3 & $30 \%$ & 60 \\
\hline Min & -0.192 & 0.016 & -0.110 & $\begin{array}{ll}0 & -0.543\end{array}$ & -3.95 & 1.57 & -28.55 & -27.80 & 40.8 & $39 \%$ & 13 \\
\hline 25 percentile & -0.037 & 0.071 & $-0.05 \mathrm{~S}$ & $9-0.489$ & -0.52 & 4.28 & -17.65 & -18.03 & 52.7 & $76 \%$ & 28 \\
\hline Median & 0.020 & 0.104 & -0.050 & $\begin{array}{ll}0 & -0.455\end{array}$ & 0.45 & 8.70 & -12.42 & -12.54 & 57.8 & $87 \%$ & 53 \\
\hline 75 percentile & 0.073 & 0.149 & -0.042 & $2-0.425$ & 1.13 & 13.44 & -6.59 & -10.05 & 62. & $46 \%$ & 70 \\
\hline $\operatorname{Max}$ & 0.350 & 0.244 & -0.030 & $0-0.341$ & 3.91 & 20.02 & -3.69 & -5.70 & 68. & $68 \%$ & 186 \\
\hline Std. dev. & 0.096 & 0.051 & 0.015 & 0.049 & 1.58 & 5.27 & 6.56 & 5.37 & & $99 \%$ & 41 \\
\hline No. of negative & 680 & 119 & 1338 & 1394 & & & & & & & \\
\hline$\%$ of negative & 0.479 & 0.084 & 0.942 & 0.982 & & & & & & & \\
\hline
\end{tabular}

In each year from 1953 to 1996 , Jones and CF-Jones models are estimated by the following cross-sectional regressions within each industry.

$$
\begin{aligned}
& \frac{\text { Accruals }_{i}}{\mathrm{TA}_{i}}=\alpha_{0} \frac{1}{\mathrm{TA}_{i}}+\alpha_{1} \frac{\Delta \text { Sales }_{i}}{\mathrm{TA}_{i}}+\alpha_{2} \frac{\mathrm{PPE}_{i}}{\mathrm{TA}_{i}}+\varepsilon_{i} \text { (Jones) } \\
& \frac{\text { Accruals }_{i}}{\mathrm{TA}_{i}}=\beta_{0} \frac{1}{\mathrm{TA}_{i}}+\beta_{1} \frac{\Delta \text { Sales }_{i}}{\mathrm{TA}_{i}}+\beta_{2} \frac{\mathrm{PPE}_{i}}{\mathrm{TA}_{i}}+\beta_{3} \frac{\Delta \mathrm{CF}_{i}}{\mathrm{TA}_{i}}+\varepsilon_{i} \text { (CF-Jones) }
\end{aligned}
$$

$\triangle$ Sales is the change in sales, PPE is gross property, plant and equipment, $\triangle \mathrm{CF}$ is the change in cash flows, and TA is total assets. The industry classification is based on the grouping in Fama and French (1997). The estimated coefficients for each industry are first averaged over the sample period. The $t$-values for estimated coefficients are also obtained based on the time-series of coefficients for each industry. The numbers in this table are the summary statistics for these average estimated coefficients and associated $t$-values across industries. 'No. of negative' is the number of coefficients less than zero, and ' $\%$ of negative' is the percentage of negative coefficients out of total 1,420 regressions.

have estimated coefficients with the expected signs (positive for $\Delta$ Sales and negative for PPE) for the CF-Jones model. The more accurate parameter estimates explain the stronger $t$-values for $\beta_{1}$ and $\beta_{2}$ than for $\alpha_{1}$ and $\alpha_{2}$.

In Tables 4 and 5, we report the separate effects of DA and NDA. Since DA is a proxy for manipulated accruals and NDA measures normal accruals, an effective accrual model should generate DA that contributes to the accrual reversals more than NDA. However, Panel A of Table 4 shows that NDA from the Jones model has more negative effects on future earnings than its DA counterpart. The difference of DA and NDA effects is statistically significant over all cumulative horizons, except for the first year. This result fully supports 


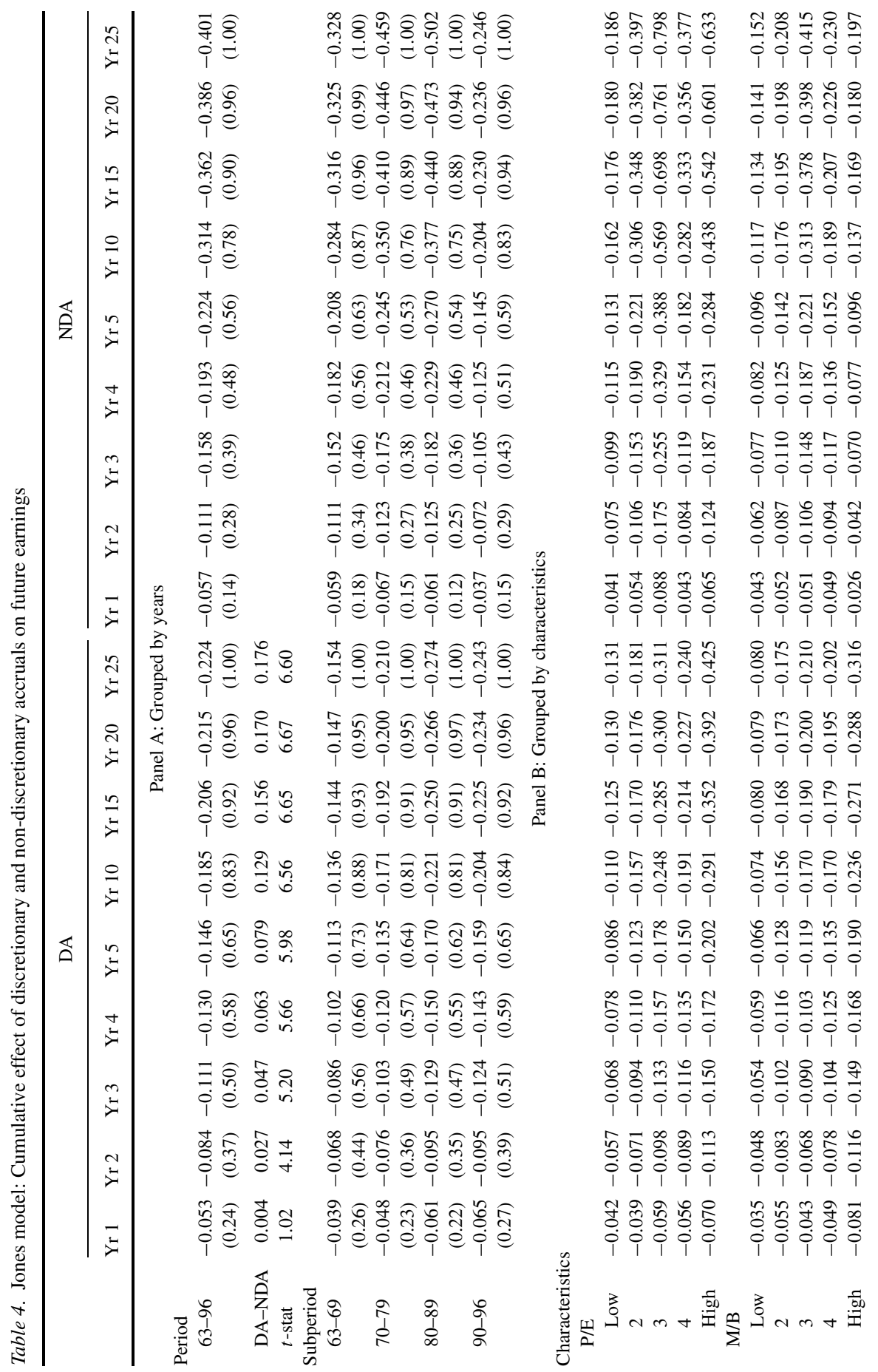




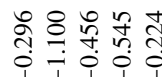

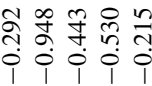

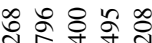

i i i i i

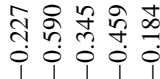

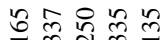

ii i i i

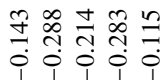

긍ำ

i i i i

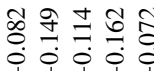

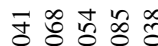

i i i i i

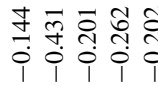

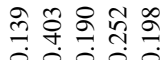

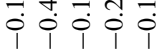

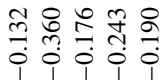

총ำ

i

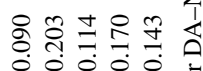

i i i i i

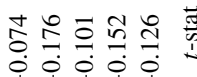

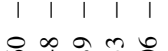

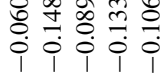

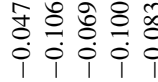

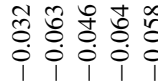

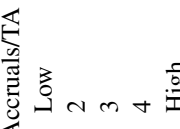

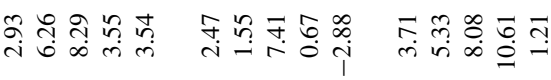

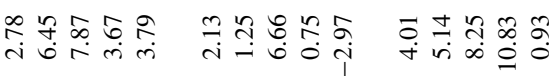

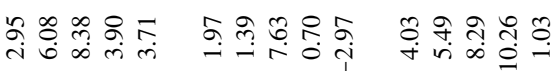

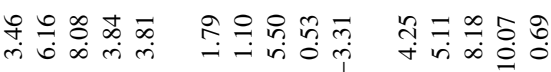

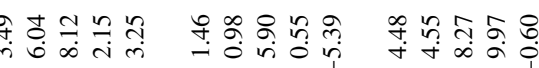

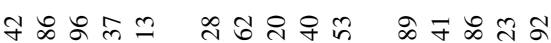

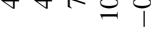

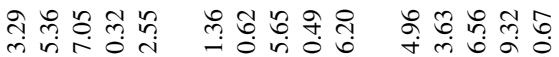

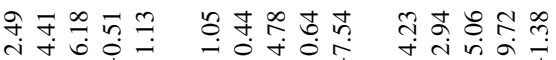

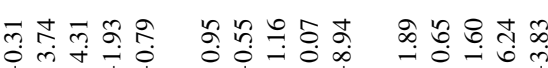

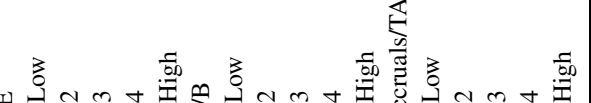

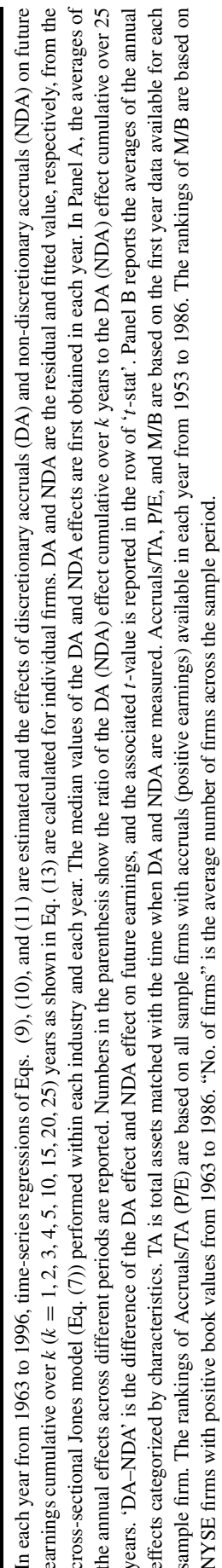




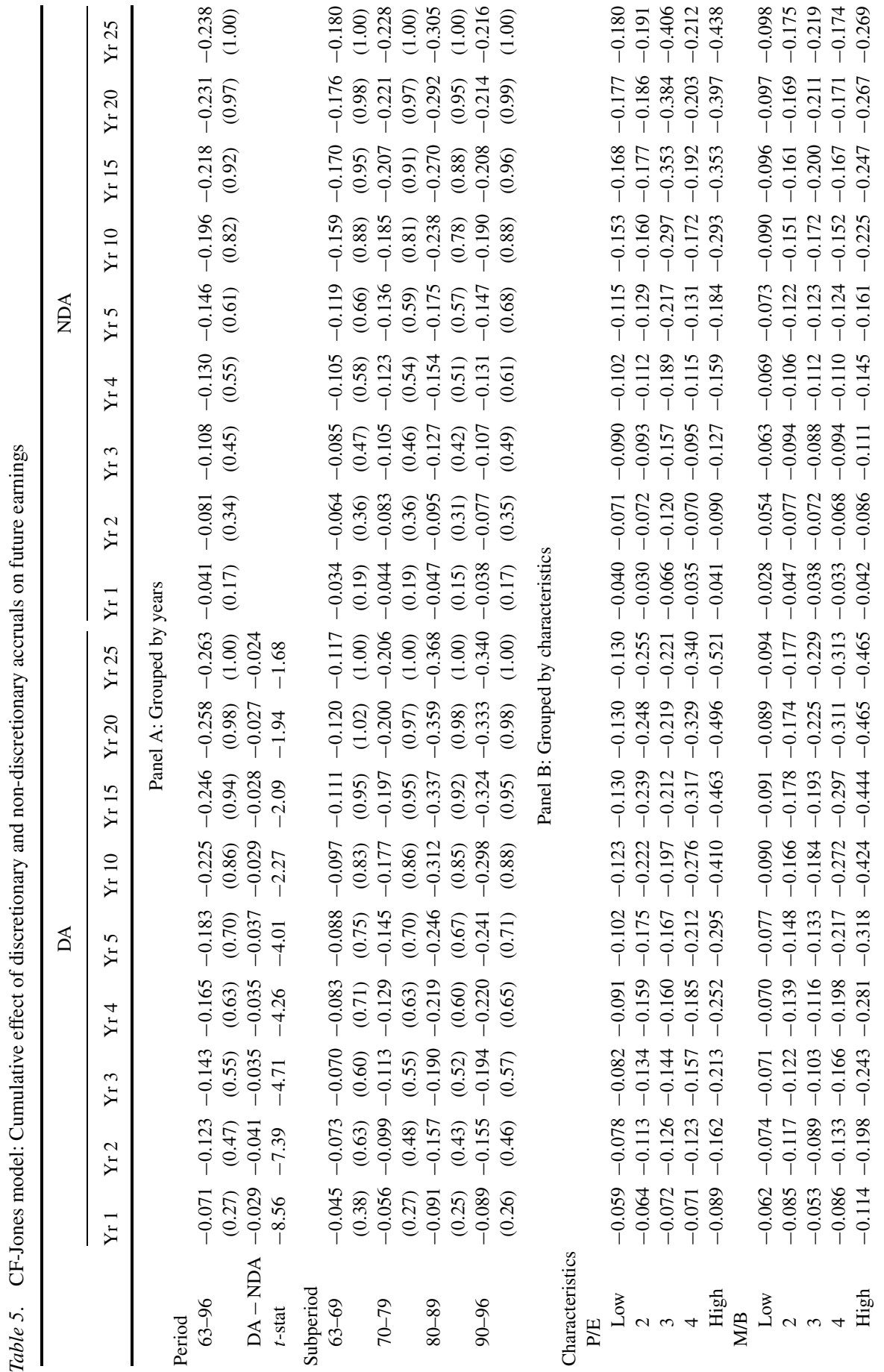




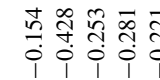

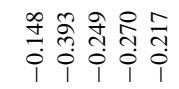

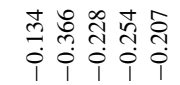

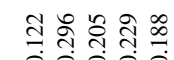

ำ

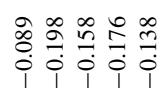

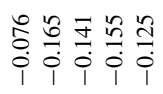

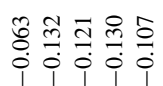

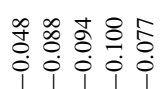

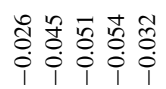

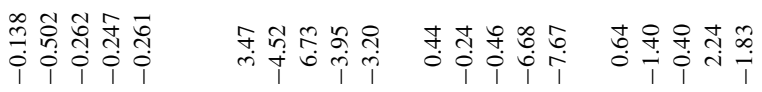

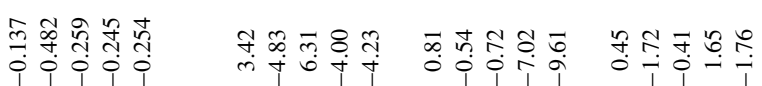

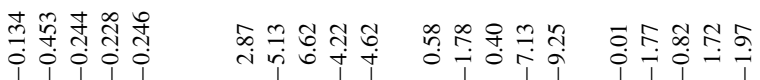

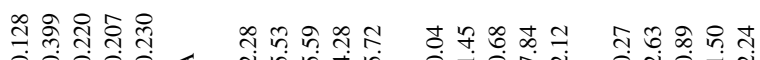

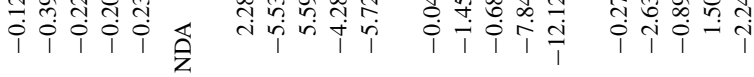

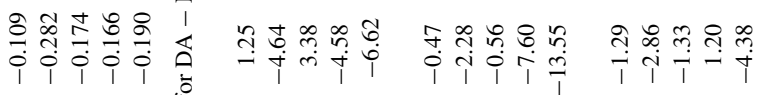

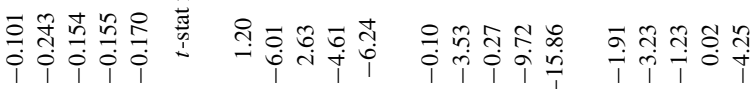

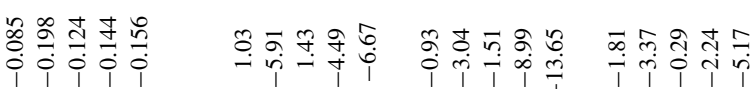

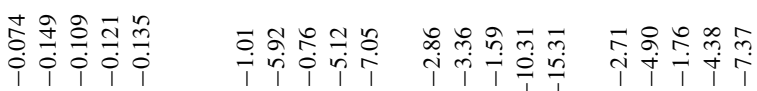

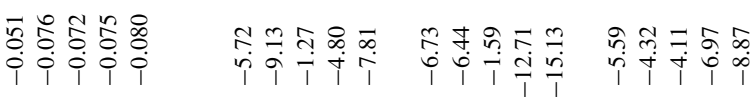

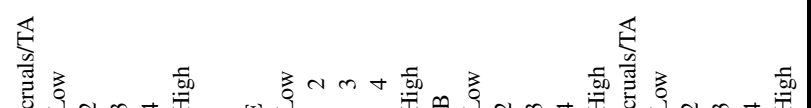

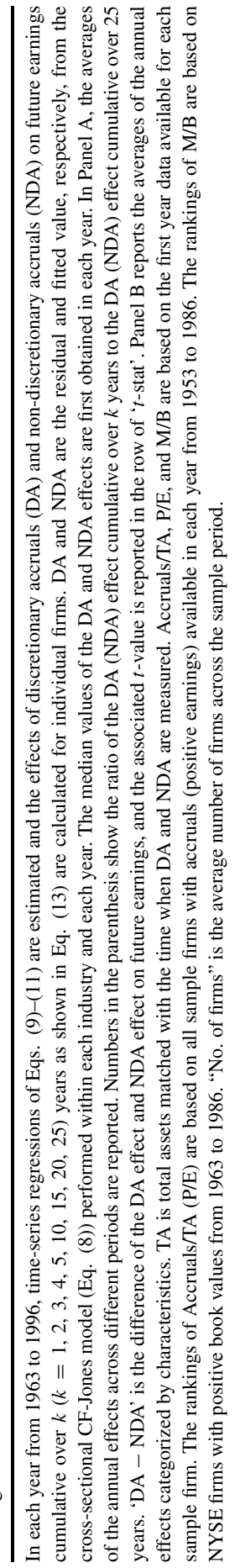


the notion in the literature that the Jones model does a poor job in identifying DA from total accruals. Panel B presents DA and NDA effects categorized by firm characteristics. NDA still has stronger effects than DA across quintiles of different characteristics, except for the highest M/B portfolio. Most of the differences between DA and NDA effects are statistically significant.

On the contrary, as shown in Table 5, DA estimated from the CF-Jones model has a significant impact on earnings while the NDA effect is smaller in most cases. On average, if firms manage earnings by inflating $\$ 1$ of DA, the aggregate earnings will decrease by $\$ 0.143$ and $\$ 0.183$, respectively, over the next three and five years. In the very long-run, $26.3 \%$ of DA will be reversed. On the other hand, the effect of inflating \$1 of NDA is smaller, with reversals of $\$ 0.108$ and $\$ 0.146$, respectively, in the next three and five years. From Panel B of Table 5, it is evident that the DA reversals are very strong for the highest $\mathrm{P} / \mathrm{E}$ and $\mathrm{M} / \mathrm{B}$ firms - 30\% of current DA reverses within five years and 50\% reverses in the long-run. DA effects are also more significant for the highest accrual firms than for the lowest accrual firms. The remarkable difference of DA and NDA effects for the highest P/E, $\mathrm{M} / \mathrm{B}$, and accrual firms supports the earnings management hypothesis that firms likely to manipulate earnings will experience more accrual reversals. While not reported here, the analysis of DA and NDA reversals classified by industries indicates that the negative DA effects are not due to a few industries. All these results in Table 5 along with its higher power to explain accrual variability (Table 3 ) suggest that the CF-Jones model is a better model in detecting earnings management.

\section{Earnings predictions}

One major application of studying accrual effects is to predict earnings by incorporating the negative accrual effects on future earnings. Panel A of Table 6 presents the earnings prediction errors for the Naive and VAR models. The predicted earnings by the Naive model exhibit consistent negative biases for different prediction horizons. On the other hand, by including the information of current accruals, the VAR model significantly reduces the negative biases in earnings forecasts. Panel B of Table 6 examines the absolute earnings prediction errors (AEPE) to test the accuracy of earnings predictions. The VAR model, on average, does not outperform the Naïve earnings prediction model. The AEPE is smaller for the VAR model in two- and three-year ahead earnings forecasts, but larger in the one-year ahead predictions. This is probably due to the increased noise introduced by accruals. ${ }^{12}$

Although the VAR model does not beat the Naive model, VAR demonstrates some promise in predicting earnings for firms with high accruals, $\mathrm{P} / \mathrm{E}, \mathrm{M} / \mathrm{B}$, volatile accruals, and long history. Panel A of Table 7 shows that VAR outperforms the Naive model for the highest accrual portfolio in different prediction horizons, though the differences are not statistically significant. In Panels B and C, the one-year ahead earnings prediction errors are smaller for the VAR model in the highest $\mathrm{P} / \mathrm{E}$ and $\mathrm{M} / \mathrm{B}$ quintiles. This outperformance persists and stays stronger for two- and three-year ahead earnings predictions. These results suggest that accruals help to predict future earnings for firms with strong incentives to manipulate earnings.

Panel D of Table 7 indicates that the earnings prediction is closely related to the variability of accruals. For firms with relatively stable accruals, adding accruals does not help to 
Table 6. Earnings prediction errors

\begin{tabular}{|c|c|c|c|c|c|}
\hline Prediction horizon & Period & No. of obs & Naive & VAR & $\begin{array}{l}t \text {-stat for } \\
\text { difference }\end{array}$ \\
\hline \multicolumn{6}{|c|}{ Panel A: Earnings prediction errors } \\
\hline \multirow[t]{5}{*}{ One-year ahead } & $63-95$ & 24732 & -0.00381 & -0.00230 & -15.34 \\
\hline & $63-70$ & 2212 & -0.00560 & -0.00549 & -0.61 \\
\hline & $71-80$ & 6566 & -0.00721 & -0.00620 & -5.47 \\
\hline & $81-90$ & 10563 & -0.00115 & 0.00085 & -12.75 \\
\hline & $91-95$ & 5391 & -0.00413 & -0.00244 & -7.52 \\
\hline \multirow[t]{5}{*}{ Two-year ahead } & $63-94$ & 21814 & -0.00485 & -0.00370 & -12.36 \\
\hline & $63-70$ & 2160 & -0.00696 & -0.00725 & 1.46 \\
\hline & $71-80$ & 6183 & -0.01061 & -0.01010 & -3.60 \\
\hline & $81-90$ & 9484 & -0.00030 & 0.00130 & -10.53 \\
\hline & $91-94$ & 3987 & -0.00559 & -0.00374 & -7.09 \\
\hline \multirow[t]{5}{*}{ Three-year ahead } & $63-93$ & 19310 & -0.00478 & -0.00410 & -6.63 \\
\hline & $63-70$ & 2106 & -0.00772 & -0.00839 & 3.17 \\
\hline & $71-80$ & 5756 & -0.01115 & -0.01108 & -0.39 \\
\hline & $81-90$ & 8644 & 0.00034 & 0.00149 & -6.51 \\
\hline & $91-93$ & 2804 & -0.00531 & -0.00376 & -6.57 \\
\hline \multicolumn{6}{|c|}{ Panel B: Absolute earnings prediction errors } \\
\hline \multirow[t]{5}{*}{ One-year ahead } & $63-95$ & 24732 & 0.0242 & 0.0243 & -1.60 \\
\hline & $63-70$ & 2212 & 0.0164 & 0.0169 & -3.04 \\
\hline & $71-80$ & 6566 & 0.0221 & 0.0220 & 0.49 \\
\hline & $81-90$ & 10563 & 0.0260 & 0.0263 & -2.09 \\
\hline & $91-95$ & 5391 & 0.0265 & 0.0264 & 0.10 \\
\hline \multirow[t]{5}{*}{ Two-year ahead } & $63-94$ & 21814 & 0.0294 & 0.0293 & 1.10 \\
\hline & $63-70$ & 2160 & 0.0219 & 0.0226 & -4.18 \\
\hline & $71-80$ & 6183 & 0.0286 & 0.0284 & 1.74 \\
\hline & $81-90$ & 9484 & 0.0312 & 0.0312 & 0.37 \\
\hline & $91-94$ & 3987 & 0.0304 & 0.0300 & 1.85 \\
\hline \multirow[t]{5}{*}{ Three-year ahead } & $63-93$ & 19310 & 0.0321 & 0.0320 & 1.66 \\
\hline & $63-70$ & 2106 & 0.0250 & 0.0255 & -2.79 \\
\hline & $71-80$ & 5756 & 0.0330 & 0.0326 & 2.55 \\
\hline & $81-90$ & 8644 & 0.0331 & 0.0331 & -0.40 \\
\hline & $91-93$ & 2804 & 0.0326 & 0.0318 & 3.83 \\
\hline
\end{tabular}

This table shows the averages of earnings prediction errors over different sample periods. In each year from 1963 to 1995 , the earnings prediction is performed based on Eqs. (14) and (15) for the VAR model, and Eqs. (16) and (18) for the Naïve model. The earnings prediction errors are defined as in Eq. (19).

account for the variation of future earnings. On the other hand, for firms with volatile accruals, incorporating accruals is useful in predicting earnings. The $t$-value for the AEPE difference between the VAR and Naive models is monotonic across quintiles sorted by accrual volatility. The AEPE difference is significantly positive for the highest accrual volatility portfolio, suggesting that the VAR model is particularly useful for firms with volatile accruals. This outperformance of VAR even persists for the two- and three-year ahead earnings predictions.

Panel E of Table 7 reports the AEPE grouped by number of annual data available for sample observations. The result suggests that using accruals is beneficial for firms with 
Table 7. One-way classifications of absolute earnings prediction errors by characteristics

\begin{tabular}{|c|c|c|c|c|c|c|c|c|c|}
\hline \multirow[b]{2}{*}{ Rankings } & \multicolumn{3}{|c|}{$\begin{array}{l}\text { One-year ahead } \\
\text { prediction errors }\end{array}$} & \multicolumn{3}{|c|}{$\begin{array}{l}\text { Two-years ahead } \\
\text { prediction errors }\end{array}$} & \multicolumn{3}{|c|}{$\begin{array}{l}\text { Three-years ahead } \\
\text { prediction errors }\end{array}$} \\
\hline & Naive & VAR & $\begin{array}{l}t \text {-stat } \\
\text { for diff }\end{array}$ & Naive & VAR & $\begin{array}{l}t \text {-stat } \\
\text { for diff }\end{array}$ & Naive & VAR & $\begin{array}{l}t \text {-stat } \\
\text { for diff }\end{array}$ \\
\hline \multicolumn{10}{|c|}{ Panel A: Ranked by accruals/TA } \\
\hline Low & 0.02520 & 0.02543 & -1.18 & 0.03075 & 0.03077 & -0.11 & 0.03400 & 0.03377 & 0.96 \\
\hline 2 & 0.02308 & 0.02365 & -3.08 & 0.02805 & 0.02802 & 0.14 & 0.03141 & 0.03120 & 0.92 \\
\hline 3 & 0.02241 & 0.02255 & -0.72 & 0.02806 & 0.02792 & 0.61 & 0.02972 & 0.02999 & -1.44 \\
\hline 4 & 0.02272 & 0.02287 & -0.96 & 0.02739 & 0.02741 & -0.20 & 0.02947 & 0.02930 & 1.13 \\
\hline High & 0.02650 & 0.02629 & 1.16 & 0.03191 & 0.03165 & 1.55 & 0.03496 & 0.03467 & 1.52 \\
\hline \multicolumn{10}{|c|}{ Panel B: Ranked by P/E } \\
\hline Low & 0.02498 & 0.02527 & -1.60 & 0.02937 & 0.02962 & -1.54 & 0.03234 & 0.03234 & -0.01 \\
\hline 2 & 0.02253 & 0.02263 & -0.58 & 0.02817 & 0.02816 & 0.03 & 0.03073 & 0.03080 & -0.42 \\
\hline 3 & 0.02260 & 0.02280 & -1.20 & 0.02838 & 0.02830 & 0.46 & 0.03047 & 0.03044 & 0.16 \\
\hline 4 & 0.02336 & 0.02332 & 0.15 & 0.02916 & 0.02897 & 1.11 & 0.03212 & 0.03196 & 0.84 \\
\hline High & 0.02538 & 0.02536 & 0.12 & 0.03032 & 0.02994 & 2.14 & 0.03320 & 0.03270 & 2.16 \\
\hline \multicolumn{10}{|c|}{ Panel C: Ranked by M/B } \\
\hline Low & 0.02729 & 0.02776 & -1.85 & 0.03165 & 0.03143 & 0.87 & 0.03343 & 0.03344 & -0.04 \\
\hline 2 & 0.02472 & 0.02467 & 0.13 & 0.02875 & 0.02865 & 0.31 & 0.03104 & 0.03106 & -0.10 \\
\hline 3 & 0.02220 & 0.02296 & -3.42 & 0.02726 & 0.02737 & -0.43 & 0.03078 & 0.03073 & 0.20 \\
\hline 4 & 0.02658 & 0.02675 & -0.61 & 0.03188 & 0.03177 & 0.42 & 0.03285 & 0.03283 & 0.09 \\
\hline High & 0.02922 & 0.02906 & 0.64 & 0.03479 & 0.03439 & 1.69 & 0.03743 & 0.03676 & 2.25 \\
\hline \multicolumn{10}{|c|}{ Panel D: Ranked by accruals volatility } \\
\hline Low & 0.01673 & 0.01729 & -4.96 & 0.02212 & 0.02230 & -1.36 & 0.02533 & 0.02555 & -1.48 \\
\hline 2 & 0.02143 & 0.02190 & -3.68 & 0.02721 & 0.02727 & -0.48 & 0.03007 & 0.03029 & -1.55 \\
\hline 3 & 0.02436 & 0.02472 & -2.33 & 0.02950 & 0.02954 & -0.29 & 0.03304 & 0.03273 & 1.63 \\
\hline 4 & 0.02806 & 0.02789 & 0.79 & 0.03379 & 0.03361 & 0.83 & 0.03558 & 0.03527 & 1.55 \\
\hline High & 0.03200 & 0.03131 & 2.24 & 0.03638 & 0.03571 & 2.64 & 0.03849 & 0.03776 & 2.34 \\
\hline \multicolumn{10}{|c|}{ Panel E: Ranked by number of years } \\
\hline $10 \leq \mathrm{yrs}<20$ & 0.02442 & 0.02460 & -1.49 & 0.02937 & 0.02932 & 0.48 & 0.03213 & 0.03201 & 0.99 \\
\hline $20 \leq \mathrm{yrs}<30$ & 0.02331 & 0.02338 & -0.59 & 0.02918 & 0.02915 & 0.29 & 0.03196 & 0.03181 & 1.08 \\
\hline $30 \leq \mathrm{yrs}<40$ & 0.02509 & 0.02531 & -1.06 & 0.03013 & 0.02989 & 1.04 & 0.03194 & 0.03192 & 0.09 \\
\hline $40 \leq \mathrm{yrs}$ & 0.02605 & 0.02517 & 2.32 & 0.03134 & 0.02952 & 2.98 & 0.03520 & 0.03233 & 3.91 \\
\hline
\end{tabular}

In each year from 1963 to 1995, the earnings prediction is performed based on Eqs. (14) and (15) for the VAR model, and Eqs. (17) and (18) for the Naïve model. The earnings prediction errors are defined in Eq. (19). This table shows the averages of absolute earnings prediction errors for quintiles of different characteristics. Accruals/TA, P/E, and M/B are based on the first year data available for each sample firm. Accruals volatility is defined as the time-series standard deviation of Accruals/TA and is calculated based on all available data up to the time of earnings predictions.

long time-series data in predicting earnings. It is reasonable to expect that the accrual effects on earnings can be estimated more accurately with longer past data and thus help in out-of-sample predictions.

Panels A and B of Table 8 present the results of OLS regressions and Fama-MacBeth regressions, respectively. The dependent variable is the AEPE difference between the VAR and Naive models. Consistent with Table 7, the relative accuracy of the VAR model in predicting earnings improves for firms with high accruals, $\mathrm{P} / \mathrm{E}$ and $\mathrm{M} / \mathrm{B}$, and high accrual 
Table 8. Regressions of difference in absolute earnings prediction errors on characteristics

\begin{tabular}{|c|c|c|c|c|c|}
\hline Intercept & Accruals/TA & $\mathrm{P} / \mathrm{E}$ & $\mathrm{M} / \mathrm{B}$ & Accruals volatility & Obs \\
\hline \multicolumn{6}{|c|}{ Panel A: OLS regressions } \\
\hline \multicolumn{6}{|c|}{ Dependent variable: Difference in one-year ahead absolute earnings prediction errors } \\
\hline $\begin{array}{l}0.00055 \\
(2.99)\end{array}$ & $\begin{array}{l}-0.00007 \\
(-2.37)\end{array}$ & & & & 24732 \\
\hline $\begin{array}{l}0.00032 \\
(1.86)\end{array}$ & & $\begin{array}{l}-0.00004 \\
(-1.32)\end{array}$ & & & 23808 \\
\hline $\begin{array}{l}0.00066 \\
(2.42)\end{array}$ & & & $\begin{array}{l}-0.00008 \\
(-1.84)\end{array}$ & & 14571 \\
\hline $\begin{array}{l}0.00097 \\
(6.43)\end{array}$ & & & & $\begin{array}{l}-0.00016 \\
(-4.52)\end{array}$ & 24732 \\
\hline $\begin{array}{l}0.00190 \\
(4.76)\end{array}$ & $\begin{array}{l}-0.00002 \\
(-0.34)\end{array}$ & $\begin{array}{l}0.00001 \\
(0.22)\end{array}$ & $\begin{array}{l}-0.00006 \\
(-0.89)\end{array}$ & $\begin{array}{l}-0.00026 \\
(-4.73)\end{array}$ & 13899 \\
\hline \multicolumn{6}{|c|}{ Dependent variable: Difference in two-year ahead absolute earnings prediction errors } \\
\hline $\begin{array}{l}0.00012 \\
(0.69)\end{array}$ & $\begin{array}{l}-0.00003 \\
(-1.28)\end{array}$ & & & & 21814 \\
\hline $\begin{array}{l}0.00026 \\
(1.56)\end{array}$ & & $\begin{array}{l}-0.00006 \\
(-2.32)\end{array}$ & & & 21019 \\
\hline $\begin{array}{l}0.00000 \\
(0.00)\end{array}$ & & & $\begin{array}{l}-0.00003 \\
(-0.75)\end{array}$ & & 12354 \\
\hline $\begin{array}{l}0.00040 \\
(2.71)\end{array}$ & & & & $\begin{array}{l}-0.00009 \\
(-3.03)\end{array}$ & 21814 \\
\hline $\begin{array}{l}0.00091 \\
(2.30)\end{array}$ & $\begin{array}{l}-0.00001 \\
(-0.16)\end{array}$ & $\begin{array}{l}-0.00004 \\
(-0.75)\end{array}$ & $\begin{array}{l}0.00002 \\
(0.35)\end{array}$ & $\begin{array}{l}-0.00018 \\
(-3.84)\end{array}$ & 11794 \\
\hline \multicolumn{6}{|c|}{ Dependent variable: Difference in three-year ahead absolute earnings prediction errors } \\
\hline $\begin{array}{l}-0.00007 \\
(-0.30)\end{array}$ & $\begin{array}{l}-0.00001 \\
(-0.40)\end{array}$ & & & & 19310 \\
\hline $\begin{array}{l}0.00014 \\
(0.73)\end{array}$ & & $\begin{array}{l}-0.00005 \\
(-1.52)\end{array}$ & & & 18634 \\
\hline $\begin{array}{l}0.00024 \\
(0.91)\end{array}$ & & & $\begin{array}{l}-0.00007 \\
(-1.65)\end{array}$ & & 10518 \\
\hline $\begin{array}{l}0.00048 \\
(2.74)\end{array}$ & & & & $\begin{array}{l}-0.00012 \\
(-3.29)\end{array}$ & 19310 \\
\hline $\begin{array}{l}0.00116 \\
(2.75)\end{array}$ & $\begin{array}{l}0.00001 \\
(0.23)\end{array}$ & $\begin{array}{l}-0.00005 \\
(-0.82)\end{array}$ & $\begin{array}{l}-0.00002 \\
(-0.34)\end{array}$ & $\begin{array}{l}-0.00020 \\
(-3.96)\end{array}$ & 10054 \\
\hline \multicolumn{6}{|c|}{ Panel B: Fama-MacBeth regressions } \\
\hline $\begin{array}{l}\text { Dependent va } \\
0.00058 \\
(3.04)\end{array}$ & $\begin{array}{l}\text { Difference in } \\
-0.00006 \\
(-1.91)\end{array}$ & ear ahead at & earnings pr & on errors & \\
\hline $\begin{array}{l}0.00036 \\
(1.90)\end{array}$ & & $\begin{array}{l}-0.00003 \\
(-0.97)\end{array}$ & & & \\
\hline $\begin{array}{l}0.00066 \\
(2.84)\end{array}$ & & & $\begin{array}{l}-0.00007 \\
(-1.70)\end{array}$ & & \\
\hline 0.00078 & & & & -0.00011 & \\
\hline$(3.72)$ & & & & $(-2.80)$ & \\
\hline $\begin{array}{l}0.00173 \\
(4.27)\end{array}$ & $\begin{array}{l}-0.00002 \\
(-0.45)\end{array}$ & $\begin{array}{l}0.00001 \\
(0.11)\end{array}$ & $\begin{array}{l}-0.00004 \\
(-0.62)\end{array}$ & $\begin{array}{l}-0.00022 \\
(-4.90)\end{array}$ & \\
\hline
\end{tabular}


Table 8. (Continued).

\begin{tabular}{|c|c|c|c|c|c|}
\hline Intercept & Accruals/TA & $\mathrm{P} / \mathrm{E}$ & $\mathrm{M} / \mathrm{B}$ & Accruals volatility & Obs \\
\hline \multicolumn{6}{|c|}{ Dependent variable: Difference in two-year ahead absolute earnings prediction errors } \\
\hline 0.00025 & -0.00003 & & & & \\
\hline$(1.47)$ & $(-1.22)$ & & & & \\
\hline 0.00047 & & -0.00007 & & & \\
\hline$(3.08)$ & & $(-3.33)$ & & & \\
\hline-0.00002 & & & -0.00002 & & \\
\hline$(-0.11)$ & & & $(-0.51)$ & & \\
\hline 0.00042 & & & & -0.00007 & \\
\hline$(2.24)$ & & & & $(-1.98)$ & \\
\hline 0.00026 & 0.00002 & -0.00003 & 0.00004 & -0.00012 & \\
\hline$(0.47)$ & $(0.55)$ & $(-0.65)$ & $(1.03)$ & $(-2.40)$ & \\
\hline \multicolumn{6}{|c|}{ Dependent variable: Difference in three-year ahead absolute earnings prediction errors } \\
\hline 0.00002 & -0.00001 & & & & \\
\hline$(0.10)$ & $(-0.30)$ & & & & \\
\hline 0.00029 & & -0.00006 & & & \\
\hline$(1.81)$ & & $(-2.37)$ & & & \\
\hline 0.00022 & & & -0.00008 & & \\
\hline$(0.99)$ & & & $(-2.01)$ & & \\
\hline 0.00040 & & & & -0.00009 & \\
\hline$(1.84)$ & & & & $(-2.21)$ & \\
\hline 0.00077 & 0.00000 & -0.00003 & -0.00002 & -0.00013 & \\
\hline$(1.38)$ & $(0.04)$ & $(-0.62)$ & $(-0.42)$ & $(-2.74)$ & \\
\hline
\end{tabular}

The dependent variables are the differences in absolute earnings prediction errors between VAR and Naïve models. In Panel A, pooled time-series cross-section regressions are estimated. The $t$-values are in the parentheses by using White's (1980) heteroskedasticity-consistent estimator of standard errors. Panel B shows the results of Fama-MacBeth cross-section regressions. The reported statistics are the means of the time series slope coefficients from annual cross-sectional regressions, and $t$-values of the mean coefficients are shown in the parentheses. All independent variables are decile rankings (with 1 lowest and 10 highest).

volatility. Among these characteristics, accrual volatility is the most important variable to distinguish the abilities of the VAR model.

\section{Conclusion}

This paper attempts to measure the impact of current accruals on future earnings. We find a strong negative relationship between accruals and aggregate future earnings. If firms manage accruals upwards by $\$ 1$ today while holding current earnings constant, on average, aggregate future earnings will fall by $\$ 0.096$ over the following three years and $\$ 0.202$ in the long-run. This negative accrual impact suggests the existence of earnings management because without the presence of earnings management accruals should not consistently affect future earnings once current earnings are controlled. With more than $20 \%$ of current accruals reversing eventually, the result also demonstrates the economic significance of accruals for future earnings.

To test the source of the negative relationship between accruals and future earnings, this paper examines the accrual effects classified by firm characteristics. The results show that 
high price-earnings stocks experience an enormous accrual impact on their future earnings, with $39 \%$ of current accruals reversing in the long-run. Firms with high market-to-book ratios also have large accrual reversals. When grouped by accruals, the accrual effects are significantly stronger for high accrual firms than for low accrual firms. Since high earnings multiples provide strong earnings management incentives and high accrual firms are more likely to have inflated accruals, the results indicate that the negative accrual effects on future earnings can be explained by earnings management.

In addition to assessing the impact of accruals on future earnings, this paper provides a new avenue to evaluate the performance of accrual models in identifying discretionary accruals which proxy for manipulated earnings. If earnings management is present, discretionary accruals obtained from an accrual model should contribute to the negative accrual effects more than non-discretionary accruals do. Two accrual models, the popularly cited Jones model and the CF-Jones model, are evaluated in this paper. We find that the Jones model significantly underperforms the CF-Jones model in explaining the cross-sectional accrual variability, with only $24 \%$ of mean adjusted- $\mathrm{R}^{2}$ for the Jones model compared to $57 \%$ for the CF-Jones model. Discretionary accruals estimated from the Jones model also consistently exhibit smaller effects on future earnings than their non-discretionary counterparts. On the contrary, the impact of discretionary accruals from the CF-Jones model is more negative than that of non-discretionary accruals. The difference is significant for firms with high price-earnings, high market-to-book, and high accruals which are more subject to earnings management. These results suggest the superior ability of the CF-Jones model in identifying manipulated earnings. Since the CF-Jones model hasn't received much attention in the literature, future research can apply this model to reexamine issues in earnings management and further explore its performance.

Given the significant accrual impact on future earnings, this paper tries to incorporate information of current accruals to predict future earnings. On average, adding current accruals improves the negative biases of predicted earnings obtained by naively extrapolating current earnings growth, but it also reduces the prediction accuracy. Nevertheless, considering accrual effects does help in predicting future earnings when accruals are volatile over time. The accuracy of earnings forecasts is also improved for firms with strong accrual effects, such as high price-earnings, high market-to-book, and high accruals.

\section{Notes}

1. Arthur Levitt, chairman of the SEC, made this comment in a speech delivered at the opening of the New York University's Center for Law and Business on September, 1998. The collapse of Enron in 2001 and subsequent financial reporting scandals, such as WorldCom, Xerox, Tyco, etc., in 2002 are vivid examples.

2. There are two other reasons why firms with high $\mathrm{P} / \mathrm{E}$ or $\mathrm{M} / \mathrm{B}$ ratios are more likely to manipulate earningsearnings overstatements are more common than understatements and this income-increasing behavior occurs usually when the stock price is relatively high. For example, both Dechow, Sloan and Sweeny (1996) and Beneish $(1997,1999)$ examine firms that are subject to SEC enforcement actions for financial reporting violations. None of their sample firms is related to earnings understatements. Burgstahler and Dichev (1997) further present the evidence of firms' tendency to prevent earnings decreases and losses, but no sign of understating income. All these results suggest that income-increasing behavior is much more popular for managers. Moreover, prior studies find that there exist significantly positive abnormal accruals prior to equity offerings (Teoh, Welch and Wong (1998a, 1998b) and Erickson and Wang (1999)). These stock issuing 
companies are generally growth firms with high P/E or M/B ratios (Brav, Geczy and Gompers (2000)). Dechow, Sloan and Sweeney (1996) also find that firms violating GAAP to boost up earnings have higher P/E and $\mathrm{M} / \mathrm{B}$ ratios.

3. Although NDA may also reverse to cause a negative effect on future earnings, we emphasize here that the DA reversal should be more significant than the reversal of NDA. In other words, if an accrual model can correctly estimate DA which proxy for manipulated earnings, the negative effect of DA on future earnings should be stronger than that of NDA. Thus, the major test of the paper is not to check if the NDA effect is negative, but focus on the differential strength between the DA and NDA effects.

4. The only existing earnings management literature which employs CF-Jones model is Kasznik (1999).

5. This is to ensure that each time-series regression (Eqs. (2) and (3)) has at least 10 observations.

6. Hribar and Collins (2002) argue that accruals based on the balanced-sheet approach (as the way we use here) suffer from measurement errors due to mergers and acquisitions, and recommend to measure accruals using cash flow statement information. However, we require 11 years of accruals for each sample firm to run regressions and the cash flow statement data are available only after 1988. Up until today, the sample firms will have at most 14 years of accruals based on cash flow statement information. Accordingly, the sample size will become much smaller if this alternative measure of accruals is used. Considering the earnings predictions, which need three extra years of data, will reduce the sample size even more. In addition, Zach (2002) examines the impact of mergers and acquisitions on the accruals return predictability documented by Sloan (1996). His empirical results suggest that mergers and acquisitions can account for at most $20 \%$ of accrual profits, and the remaining $80 \%$ is left unexplained. This indicates that mergers and acquisitions are not likely to explain the entire consequences of earnings management. Therefore, we believe that the accrual reversal we show in this study cannot be exclusively due to measurement errors in estimating accruals. Nevertheless, future research may explore how much of the accrual reversal is due to measurement errors in accruals when there are long enough data in cash flow statements.

7. One may wonder whether the assumption of first-order VAR is valid for earnings and accruals. We run Eq. (2) by adding two lagged accruals, and find that only the coefficient of the current accruals $\left(a_{2}\right)$ but not of lagged accruals is statistically significant.

8. We perform the augmented Dicky-Fuller (ADF) test on earnings and accruals separately. For earnings series, there are 51 firms whose $t$-values are larger than -1.61 , and 83 firms whose $t$-values are larger than -1.95 . For accrual series, there are only 6 firms with $t$-values higher than -1.61 , and 14 firms with $t$-values higher than -1.95 . Since the critical value at $10 \%$ for the ADF test is -1.61 , only about $2 \%$ of the sample firms have a unit root in their earnings series and $0.2 \%$ in the accrual series. Even based on $5 \%$ critical value $(-1.95)$, less than $3 \%(0.5 \%)$ of firms have a unit root in their earnings (accruals) data.

9. We run time-series regressions for each sample firm as long as it has at least 11 annual earnings and accruals data (to meet the 10 observations criterion). For example, if a firm has annual data from 1980 to 1996, we first run regression Eqs. (2) and (3) using data from 1980 to 1990, and get the estimate of the transition matrix Q. Based on $\mathbf{Q}$, we can estimate the accrual effect on next period earnings, and based on $\mathbf{Q}^{2}$, we can estimate the impact of accruals on earnings two periods later, etc. In 1991, we add one more observation in Eqs. (2) and (3) and repeat the same process to estimate $\mathbf{Q}$ and the accrual effect. This procedure is repeated up to the last year with valid data.

10. To avoid the explosion of long-term accrual effects, we first calculate the median of accrual effects for each sample year, and then compute the mean value of these annual median accrual effects. To further reduce the impact of outliers, we eliminate the observations whose 25 -year accrual effects are within top or bottom $5 \%$. However, the results are very similar if outliers are kept.

11. About $66 \%$ of the time-series regressions have negative accrual effects over each cumulative horizon.

12. The average standard deviation is $7.14 \%$ for accruals and $4.18 \%$ for earnings based on time-series data of individual firms.

\section{References}

Beneish, M. D., "Detecting GAAP Violation: Implications for Assessing Earnings Management Among Firms with Extreme Financial Performance." Journal of Accounting and Public Policy 16, 271-309 (1997). 
Beneish, M. D., "Incentives and Penalties Related to Earnings Overstatements that Violate GAAP." Accounting Review 74, 425-457 (1999).

Bernard, V. L. and D. J. Skinner, "What Motivates Managers' Choice of Discretionary Accruals.” Journal of Accounting and Economics 22, 313-325 (1996).

Bernstein, L., Financial Statement Analysis, 5th ed., Irwin, Homewood, IL (1993).

Brav, Alon, C. Geczy and P. A. Gompers, "Is the Abnormal Return Following Equity Issuances Anomalous?" Journal of Financial Economics 56, 403-416 (2000).

Burgstahler, D. and I. Dichev, "Earnings Management to Avoid Earnings Decreases and Losses." Journal of Accounting and Economics 24, 99-126 (1997).

Campbell, J. Y. and J. Ammer, "What Moves the Stock and Bond Markets? A Variance Decomposition for Long-Term Asset Returns.” Journal of Finance 48, 3-37 (1993).

Chan, K., L. K. C. Chan, N. Jegadeesh and J. Lakonishok, Earnings Quality and Stock Returns, Working Paper, University of Illinois at Urbana-Champaign (2003).

Dechow, P. M., "Accounting Earnings and Cash Flows as Measures of Firm Performance: The Role of Accounting Accruals." Journal of Accounting and Economics 18, 3-42 (1994).

Dechow, P. M., S. P. Kothari and R. L. Watts, "The Relation Between Earnings and Cash Flows." Journal of Accounting and Economics 25, 133-168 (1998).

Dechow, P. M., R. G. Sloan and A. P. Sweeney, “Detecting Earnings Management.” Accounting Review 70, $193-225$ (1995).

Dechow, P. M., R. G. Sloan and A. P. Sweeney, "Causes and Consequences of Earnings Manipulation: An Analysis of Firms Subject to Enforcement Actions by the SEC." Contemporary Accounting Research 13, 1-36 (1996).

Defond, M. L. and J. Jiambalvo, "Debt Covenant Violation and Manipulation of Accruals.” Journal of Accounting and Economics 17, 145-176 (1994).

Erickson, M. and S. Wang, "Earnings Management by Acquiring Firms in Stock for Stock Mergers." Journal of Accounting and Economics 27, 149-176 (1999).

Fama, E. F. and K. R. French, "Industry Cost of Equity.” Journal of Financial Economics 43, 153-193 (1997).

Guay, W. R., S. P. Kothari and R. L. Watts, “A Market-Based Evaluation of Discretionary Accrual Models.” Journal of Accounting Research (Suppl.) 34, 83-105 (1996).

Healy, P., "Discussion of a Market-Based Evaluation of Discretionary Accrual Models." Journal of Accounting Research (Suppl) 34, 107-115 (1996).

Hribar, P. and D. W. Collins, "Errors in Estimating Accruals: Implications for Empirical Research." Journal of Accounting Research 40, 105-134 (2002).

Jones, J. J., "Earnings Management During Import Relief Investigations.” Journal of Accounting Research 29, 193-228 (1991).

Kasznik, R., "On the Association Between Voluntary Disclosure and Earnings Management." Journal of Accounting Research 37, 57-81 (1999).

Kieso, D. E. and J. J. Weygandt, Intermediate Accounting, 9th ed. New York, NY: John Wiley \& Sons, (1998).

Schilit, H. M., Financial Shenanigans, New York, NY: McGraw-Hill, Inc. (1993).

Sloan, R. G., "Do Stock Prices Fully Reflect Information in Accruals and Cash Flows About Future Earnings." Accounting Review 71, 289-315 (1996).

Subramanyam, K. R., "The Pricing of Discretionary Accruals." Journal of Accounting and Economics 22, 249-281 (1996).

Teoh, S. H., I. Welch and T. J. Wong, "Earnings Management and the Long-Run Market Performance of Initial Public Offerings.” Journal of Finance 53, 1935-1974 (1998a).

Teoh, S. H., I. Welch and T. J. Wong, "Earnings Management and the Underperformance of Seasoned Equity Offerings." Journal of Financial Economics 50, 63-99 (1998b).

Zach, T., Inside the accrual anomaly, working paper, Washington University (2002). 